\title{
Individuality and Individualism A Culturological Interpretation ${ }^{1}$
}

\author{
LESLIE A. WHITE \\ The University of Michigan, U.S.A.
}

\begin{abstract}
$\mathrm{T}$
HIS paper undertakes an inquiry into the nature of individuality, and reviews doctrines of individualism well entrenched in contemporary American thought, especially in anthropological theory.

An individual is a distinguishable member of a class of things or events. One member of a class can be distinguished from others by its discreteness on the one hand, and by its particular features, on the other. But, even if members of a class had no particular features, their very discreteness would give each an individuality. An atom of copper would have individuality even if it were exactly like every other atom of copper. But no two atoms are exactly alike; just as no two peas or mice or men are exactly alike. And we could not speak of two things being exactly alike, or of two things at all, if they were not distinguishable discretely. We see individuality, therefore, in its relationship to the continuum, on the one hand, and to particular characteristics on the other. Given complete likeness, theoretically, individuality is realized through discreteness. Given discreteness, individuality may be further expressed through particular characteristics.

But the factor of discreteness is not as simple as it appears at first glance. Viewed superficially, a thing or event may appear to be discrete or not-discrete, with no intermediate positions. Sometimes this is the case, but it is not always so. The individuality of a brick is determined by its discreteness on the one hand and by its intrinsic properties on the other; its individuality is not determined by its relationship to other bricks except in so far as it is a member of a class.

But it is otherwise with living organisms. An ape is an ape. But his individuality is affected by his relationships with other apes. These relationships are of two kinds: genetic and sociological. As a physical object, his discreteness is entire and complete. As a biological organism, his discreteness is complete in one respect but not in another. He is a complete, autonomous whole, and he
\end{abstract}

1 This paper was presented at meeting of The American Studies Association of Texas at the University of Texas, Austin, on November 30, 1962. It is published here through the courtesy of the American Studies Association and by permission of the University of Texas. 
could continue to exist even if all other apes were suddenly extinguished. But as a biological organism, his discreteness is not entire and complete; his individuality has been affected by the organisms of his forebears. He is what he is because his genetic composition has been determined by those of his parents, and by their parents in turn. $\mathrm{He}$ is both a genotype and a phenotype; his individuality is a function of both phylogeny and ontogeny.

The individuality of an ape is, therefore, of a different order from that of a brick. The individuality of the latter is wholly a matter of discreteness within a uniformity of a class of things. The individuality of the former is the product of a qualified discreteness, on the one hand, and of variation among the members of the class, on the other. But the important thing, for our present purposes, is that the individuality of a brick, in so far as it arises from particular characteristics rather than from mere membership in a class, is not affected, or determined, by other bricks, whereas the biological individuality of the ape is profoundly affected by other apes.

Individuality among apes is affected by their interrelationships on a sociopsychological level as well as upon a biological level. The individuality of an ape is determined not only by his genetic constitution but also by his social relations with other apes. Apes differ in age, sex, size, strength, prowess, etc., and these differences find significant expression in social behavior. The role that an ape plays in the social life of his troop will be determined by the actions and interactions of other apes as well as by his own physiological and morphological properties. In short, the personality - the individuality - of the ape will be determined socially as well as genetically. So significant is the social factor in this respect, that a close scientific observer has remarked that "it is hardly an exaggeration to say that a chimpanzee kept in solitude is not a real chimpanzee at all" (Kohler, 1926, p. 293). He goes on to point out that the behavior of the chimpanzee, i.e., his social individuality, is a function of the behavior of other members of his group.

The dependence of chimpanzees, not merely upon the behavior of their fellows, but upon an actual social tradition that exists in chimpanzee society in their natural habitat, is vividly set forth by Heini P. Hediger of the Zurich Zoo and University. Why is it, he asks, that so few chimpanzees have been born in zoological gardens: "the number of chimpanzee births lags far behind that, for example, of giraffes and hippopotami" (Hediger, 1961, p. 44). The reason, he says, is that chimpanzees reared in zoos do not know how to perform the act of copulation.

"Fully grown chimpanzees are hardly ever caught in Africa, and consequently cannot be exported. The rule is, rather, for babies or barely weaned young, whose parents have been killed, to reach the zoos, where, over the years, they develop into sexually mature specimens. In this manner, that is, through the importation of unknowing young animals, the chain of natural tradition is interrupted. The young that have grown up in isolation literally do not know what to do with their sexual urge upon maturity... In many cases, mature pairs, out of ignorance, never get past the stage of sterile masturbation" (ibid., p. 45). 
We have here a truly remarkable situation. Among lower forms of life the act of procreation is performed instinctively. But among the great apes, at least, and in the human species this kind of behavior must be learned. Now, as we noted a moment ago, the behavior of a chimpanzee is not merely a function of the behavior of other chimpanzees, as pointed out by Kohler. It is dependent upon a social tradition which, in a state of nature, is passed down from one individual and generation to another. This tradition is broken when chimpanzees are taken in infancy from their parents and other elders and reared in zoos, either in solitude or among other chimpanzees similarly divorced from the social tradition of mating. Therefore, the mere presence of other chimpanzees is not enough to enable a chimpanzee to perform the act of mating; the actual social tradition of mating must be there also.

We see, then, in this situation that the individual chimpanzee is not only dependent upon the behavior of other chimpanzees to bring out and express his own innate nature, but is dependent upon a social tradition that we can distinguish logically from the continuum of biological parents and children. Indeed, the whole species is dependent upon this tradition; without it they could not mate; they would become extinct.

The individuality of an ape differs significantly from that of a brick. Among bricks there is a maximum of discreteness, a minimum - or near minimum of particular variation. Among apes, however, discreteness is profoundly qualified on both the biological level and the socio-psychological level. An ape's individuality is a function of - and consequently subordinated to or limited by - his genetic inheritance, the behavior of his fellows, and social tradition. Individuality becomes but a more or less particular expression of two continuums: one biological, the other socio-psychological.

Turning now to the species Homo sapiens, we note that a man may be considered in three contexts : as a physical object, as a mere animal, and as a human being. Man is, of course, an animal, but he is a unique animal. Only man is capable of originating, determining, and bestowing, freely and arbitrarily, meanings upon things and events in the external world, meanings which cannot be grasped and appreciated with the senses. Holy water is a case in point. Holy water is not the same thing as mere tap water. It is distinguished from ordinary water by a characteristic that is significant to human beings. But this distinguishing characteristic, this meaning or value; cannot be perceived. We call this ability of man to bestow such meanings the ability to symbol. Symboling includes the ability to comprehend non-sensory meanings as well as to originate and bestow them. Symboling, then, consists of traffic in non-sensory meanings. Articulate speech is another example of symboling and is, probably, its most important and characteristic form of expression (see "The Symbol, etc.," in White, 1949a).

All of civilization, or culture, is dependent upon articulate speech. We could not have ideologies, customs, or institutions without articulate speech. Even the human use of tools, as distinguished from tool-using among apes, is, as I have argued elsewhere (White, 1942), dependent upon the ability to symbol. We 
find, therefore, that man, as a human being, inhabits a world of his own, a unique world, as well as occupying, as a mere animal, the world that apes live in. A human being is subject to the same influences of gravitation, temperature, atmospheric pressure, and humidity as an ape - and, indeed, a brick - is. But here the similarity between the physical worlds of an ape and of a human being ends. Culture conditions and qualifies all of man's perceptions - as a human being - of the external world. He does not see the same sun that an ape sees. To the ape the sun is merely an optical and thermal object. But to a human being it is the Sun Father, the Giver of Life, or a huge mass of thermonuclear transformations.

We turn now to the question of individuality in the human species. A man is a discrete physical object as a brick is. As a biological organism he is discrete as an ape is. That is, in so far as he is a complete, autonomous system his discreteness is complete. But this system, this organism, is not wholly discrete with reference to other organisms; its characteristics have been determined genetically by other organisms, namely, his ancestors. But when we turn to the socio-psychological context, we find that it is culture, rather than mere social interaction or merely a behavioral tradition that is significant. The individuality of a human being has, therefore, three determinants: first, the discreteness of a complete, autonomous animate material system; second, the factor of genetic inheritance which tends to limit and constrain individuality by making a child resemble his parents; and, third, the influence of the extra-somatic tradition that we call culture.

Mere social interaction and social tradition are, as we have seen, factors in the determination of individuality among apes. Both of these factors are biologically determined. The process of social interaction is determined by such factors as age, sex, size, strength, health and prowess. Their social tradition - at least in the conspicuous instance of reproduction - is merely a device to facilitate the expression and to guarantee the continuity of a biological process. In the human species, however, both mere social interaction and social tradition are culturally, rather than biologically, determined. It is not, for example, innate biological traits that determines the form of the family or the social traditions of monogamy and polygamy. On the contrary, it is the extra-somatic tradition that we call culture that determines the behavior of the members of the family. And culture is an organization, or system, that behaves in accordance with its own principles and laws. Let us turn, then to this factor and see how it operates and, specifically, how it affects human individuality.

Culture and man as a human being began simultaneously; both originated in symboling. Symboling produced culture: an organization of beliefs, customs, tools, and techniques. In a relatively short time, every society of men acquired a complete, even though simple and crude, culture, and in so doing these men became completely humanized. This culture was transmitted from one generation to another; it flowed down through time indefinitely. It acquired a life of its own, so to speak. It became a process sui generis, self-contained, self-determined, and autonomous. To be sure, culture could not exist without human beings. 
But it is not human beings who determine their culture by desire and design; it is culture that determines the behavior of peoples. The behavior of the culture process, or of cultural systems, is not a function of the human mind; on the contrary, the behavior of peoples is a function of the extra-somatic tradition that is culture (we say peoples, not individuals, because the behavior of an individual is a function of his biological make-up as well as of his culture). The culture process, or cultural systems, behave in accordance with principles and laws of their own. Culture is to be explained culturologically rather than biologically or psychologically. There is, of course, a necessary and intimate relationship between culture as a whole and the human species. If man were not the kind of animal he is, his culture in general would not be what it is. But we cannot explain variations of culture in terms of the biological factor, man. The problems of culture history and the evolution of culture do not require for their solution a consideration of the human organism or species. The culturologist approaches the problems of culture change as if the human race did not exist.

What is the nature of individuality of human beings within the culture process (or cultural system) ? ${ }^{1}$ They have individuality of a sort, but it is so subordinated to the influence of the extrasomatic tradition of culture as to be almost an individuality without distinctiveness. It is much like the individuality of bricks: each is distinct, but all are made of the same materials and designed in the same way. Let us consider what takes place in the making of a human being.

An infant of the human species is born into a cultural tradition. At birth, and for some time thereafter, the infant's potential ability to symbol does not reach the point of overt expression. The pre-symbol child is not a human being from the standpoint of kind of behavior. The infant becomes humanized as he is inducted into his culture through the process of symboling. In this way he acquires all his knowledge and beliefs, his customs and his codes, his attitudes and values, his gods and his hells. A human being is a receptacle into which culture has been poured.

To be sure, the human organism is not a wholly passive object. On the contrary, it is a dynamic system, a thermodynamic system. It does not merely undergo experiences; it does something about them. Cultural influences impinge upon the human organism; elements of culture are introduced into it. And the human organism, as a dynamic system, lays hold of them, orders them, correlates and synthesizes them. No two human organisms do this in precisely the same way, first because no two organisms are exactly alike, and second because the order in which the organism experiences cultural events is significant. Two organisms, exactly alike biologically, and reared in the same cultural milieu, could become different persons as a consequence of the order in which they underwent certain experiences. Two young women, for example, could (1) go to college, (2) have a baby, and (3) marry. But the order in which each one did these things would have a significant effect upon her as an individual.

There is room, then, for individuality among human beings as a consequence

1 See White, $1949 \mathrm{~b}$ and 1950 for a previous discussion of this subject. 
of (1) their respective biological differences, (2) differences in the temporal order in which events are experienced, and (3) variations of the cultural factor itself; in a complex cultural system one person might be reared in one sub-culture, another person in another. But the similarity among human beings produced by a given culture is striking. Culture exerts a powerful and overriding influence upon the biological organisms of Homo sapiens, submerging the neurological, anatomical, sensory, glandular, muscular, etc., differences among them to the point of insignificance.

I remember vividly when, as a youth, I heard for the first time Negroes speaking French. I had lived in a rural area in the Deep South where all Negroes spoke, not merely the English language, but a distinctive dialect of that tongue. Consequently, years later, I experienced a shock of novelty and of unreflecting surprise when in the West Indies I heard Negroes speaking French - much as if I had suddenly heard a turkey quack.

Language and dialects impose themselves upon the plastic infant organisms that come under their influence. To be sure, no two persons speak a dialect in exactly the same way. But, when one considers the enormous range of biological differences - the endomorphs and exomorphs, the hypothyroid and the hyperthyroid, the prognathous and hypognathous, and all the variations of bony, muscular and neural structure - the similarity of the product, of the dialect spoken, is truly impressive. So impressive, in fact, that one well versed in the geography of dialects can tell where a person was reared by the way he pronounces a few words. And so profoundly does the linguistic tradition influence the organism of a human being that it becomes virtually impossible for him, after he has passed the stage of adolescence, to learn to speak another language without an appreciable accent. It is almost like having been reared a turkey it becomes impossible to quack. The linguistic tradition is like a radio broadcasting station; the organism, like the radio that receives the message and reproduces it. If the culture broadcasts Tibetan, the human radios "play" Tibetan; if it broadcasts a Brooklyn dialect of English, the human organism will reproduce that.

As it is with language in particular, so it is with culture as a whole. Just as your culture imposes a language and dialect upon you, so does it equip you with your beliefs, your customs, your attitudes and values. The individual is but a particular recreation of his culture.

It is ironical that, notwithstanding the fact that this conception of human individuality has been developed and validated by cultural anthropology, we nevertheless find a totally opposed conception which we shall now examine and which is well established in anthropological theory. In this respect, however, anthropology does but reflect a more general and popular conception of individuality. The anthropologists who hold this anthropocentric conception of individuality do so not because of anthropological science, but in spite of it.

The conception of individuality which we are about to examine is, as we have just indicated, an anthropocentric one. Thesis: It holds that the human individual is a complete and self-determined whole, and that he is, moreover, 
a dynamic system, a prime mover, a creator, a first cause. In its extreme form, this conception insists that only individuals are real - society is merely an aggregation of individuals, and culture but an abstraction.

This exact opposite of a culturological interpretation was espoused by the late Franz Boas, who dominated American anthropology for many years after the turn of the century. "It seems hardly necessary," he wrote, "to consider culture a mystic entity that exists outside the society of its individual carriers and that moves by its own force... The forces that bring about the changes are active in the individuals composing the social group, not in the abstract culture" (Boas, 1932a, pp. 245-46).

\section{Comment}

Of course culture is not a mystic entity, but there is a very real sense in which it has an existence outside of the individuals who comprise a society. ${ }^{1}$ All material culture - buildings, factories, railroads, etc. - have, of course, their objective being outside individuals. But so also do intellectual and social traditions. The English language, the Ten Commandments, Euclidean geometry, and codes of laws had an existence before any of us was born; they enter our minds from the outside; and they will continue to exist after we are gone. It is self-evident that culture could not "move" were it not for human beings which make the culture process possible. But from the standpoint of a scientific explanation of the process of culture change, we do not need to take individuals into account; indeed we may disregard human beings entirely. We do not need, for example, to concern ourselves with human beings when we deal with such matters as the diffusion of the use of tobacco throughout the world after the discoveries of Columbus, or the evolution of currency, or of the constitutional, parliamentary form of government. People could not solve problems in algebra or compose symphonies were it not for respiration. But we do not need to take respiration into account in a scientific explanation of such behavior.

\section{Thesis}

The anthropocentric, anti-culturological point of view is frequently expressed in the assertion that it is people, not culture, that does things. "But culture does not 'work,' 'move,' 'change,' but is worked, is moved, is changed. It is people who do things..." says Robert S. Lynd. He goes on to say, "The culture does not enamel its fingernails, or vote, or believe in capitalism, but people do" (Lynd, 1939, pp. 38, 39). And Edward Sapir, a prominent student

1 "...collective ways of acting and thinking [i.e., culture] have a reality outside the individuals who, at every moment of time, conform to it. These ways of thinking and acting exist in their own right. The individual finds them completely formed, and he cannot evade or change them. He is therefore obliged to reckon with them." Emile Durkheim, The Rules of Sociological Method. Preface to the second edition, p. Ivi (Chicago, 1938). 
of Boas, declares that "it is always the individual that really thinks and acts and dreams and revolts" (Sapir, 1917, p. 442).

Comment

Of course it is people who enamel their fingernails; as a matter of fact, culture has no fingernails. And thinking and dreaming are processes that have their loci in individual biological organisms. But the intent and purpose of Lynd and Sapir are not to utter these commonplaces, but to express a philosophy of behavior. From the standpoint of science, the question is not who does this or that, people or culture, but why do people do the things they do. And the reason why one people enamels their fingernails while another blackens their teeth, or tatoos their faces, is because they are responding to different extrasomatic cultural traditions. And as for thinking and dreaming, these are processes which, by definition, take place within a biological organism. But what the individual thinks and dreams is determined by his culture: a Hottentot does not think or dream as does a Frenchman.

\section{Thesis}

Some outstanding and influential anthropologists have conceived of the individual as a First Cause. "The individual, with his physiological needs and psychological processes," said Malinowski, "is the ultimate source... of all tradition, activities, and organized behavior" (Malinowski, 1939, p. 962). Similarly, Goldenweiser "places the individual both at the beginning and at the end of the social process. Human society," he says, "was built out of the needs, proclivities and achievements of individuals..." (Goldenweiser, 1935, p. 75). Thus, to these students, it is the individual who creates culture. "It is the individual," said Ralph Linton, "who is responsible, in the last analysis, for all additions to culture. Every new idea must originate with some person" (Linton, 1938, p. 248). To Edward Sapir, "any culture element... has radiated out, at last analysis (the phrase "last analysis" suggests that there is nothing more to be said, L.A.W.), from a single individual" (Sapir, 1916, p. 43). "The inventive process resides in individual organisms," says Clark Wissler; "it is a function of the individual organism" (Wissler, 1927, p. 87). Ruth Benedict, too, has offered an "in the last analysis" pronouncement: "no civilization has in it any element which in the last analysis is not the contribution of an individual. Where else could any trait come from except from the behavior of a man or a woman or a child?" (Benedict, 1934, p. 253).

Let me hasten to point out that this conception of the individual's role in the culture process is not confined to anthropology. William James expressed it long ago in his essay, "Great Men, Great Thoughts and the Environment." The genesis of great ideas, and inventions is, he says, "sudden and, as it were, spontaneous... [a] conception... is a spontaneous variation in the strictest sense of the term... [inventions such as the yard-stick, the balance, the chronometer] 
and all other institutions were flashes of genius in an individual head, of which the outer environment showed no sign" (James, 1880, pp. 456-58; emphasis mine).

\section{Comment}

It all seems so simple and so obvious: where else could an invention occur, a new culture trait originate, except in the mind of "a man or a woman or a child"? Simple and obvious, perhaps, but so anthropocentric. How could a human individual, divorced from culture, invent or originate anything cultural? In the first place, as we have already seen, an individual, divorced from a cultural milieu would not be a human being; he would be a mere hominid. Furthermore, without cultural material to work with the individual could do nothing of cultural significance. An invention - a new conception, a new tool, or a new institution - is a novel permutation or combination of culture traits effected within the interactive process that is a cultural tradition. An invention - the steam engine, for example - is a synthesis of already existing cultural elements the technique of making fire, metallurgy, cylinders, pistons, cranks and wheels. The steam engine has a genealogy. It is the culturological descendant of many elements of culture, each of which in turn can be traced back in time, sometimes to remotest antiquity, such as is the case of fire-making. The "invention of the steam engine" was not a single event, achieved by a single individual, but a socio-technological process involving the labor of scores of individuals in several nations over a period of more than a century. The fact that dozens of inventions and discoveries have been made simultaneously by two - sometimes several persons working quite independently of one another is a significant indication of cultural determination rather than of individual initiative or genius. When the interactive culture process reaches a certain point of development, an invention or discovery becomes not only possible but inevitable (White, 1949, pp. 168-70, 203-11; see, also, Wm. F. Ogburn and Dorothy Thomas, "Are Inventions Inevitable?" Political Science Quarterly, Vol. 37, pp. 83-98, 1922).

To go back to a point that we have touched upon before, if one means merely that neurological processes of individual organisms are essential to the synthesis of elements in the extrasomatic cultural tradition (Kroeber and Kluckhohn [1952, p. 172] say that "each new or changed value takes its concrete origin [as do all aspects of culture] in the psychological processes of some particular individual), then of course we must grant that this is true. Neurological processes are essential to the social process of culture change and invention, and by definition, they are functions of the biological organism, not of the social organism, or body politic. But to say, as William James did, or to imply as others have done, that the individual is the creator, the originator, the prime mover is a gross distortion, an example of crass anthropomorphism. To say that a man invented something because he was a genius (as William James did) is one thing; to say that the individual was the locus within which a significant synthesis of cultural elements took place is quite another. To be sure, one human organism may be a better neurological locus than another, but we have no way 
of measuring the innate inventive capacity of a nervous system directly. To say that one who has made a great invention is a genius, i.e., has superior innate ability, is to make a neurological inference from culturological evidence. And to account for a great invention in terms of such genius is to explain the known facts of culturology by the unknown facts of neurology - which is not very good science.

\section{Thesis}

With regard to the question of culture change in general, many anthropologists have held that here also, as in the case of invention, it is the individual who effects the changes. "When patterns [of culture, L.A.W.] change," says the British social anthropologist, Raymond Firth, "it is individuals in the last resort [sic] who change them" (Firth, 1951, p. 85). Indeed, they conceive of individuals standing outside their culture and, by their own actions, changing it - in the same way that man can, and has, changed natural environments by deforestation, irrigation or drainage, exterminating vast herds of bison, and bringing prairies under cultivation. Thus, Franz Boas not only distinguishes between the culture that he lives in, on the one hand, and his ideals on the other, but tells us that the culture "ran counter" to his ideals (Boas, 1938, p. 204).

Naturally, exceptionally able individuals are more likely to change their cultures than mediocre ones, according to this thesis. In small groups of primitive peoples, says Lowie (1948, p. 84), "a few resolute spirits can easily impose an innovation." "Dominant personalities" effect changes in art, science, philosophy and literature, according to Goldenweiser (1922, p. 26). To turn to nonanthropologists, William James asserts that culture change "is due to the accumulated influences of individuals, of their examples, their initiatives, and their decisions" (op. cit., p. 242). And Arnold Toynbee - according to Roger J. Williams - "makes clear the crucial importance of individual creative souls in any society and indicates that the breakdown of any civilization is primarily traced to the failure in the creative power of the individuals who should be like leaven in the lump" (Williams, 1950, p. 54).

But it is not only the "dominant personalities," the "resolute spirits," and the "creative souls" who change the course and content of culture, according to this view. The unstable, the maladjusted, and the non-conformists also produce changes. William James (op. cit., pp. 456-57) says that a conception "flashes out of one brain, and no other, because the instability of that brain is such as to tip and upset itself in just that particular direction."

It is the dissatisfied and the dissident who bring about culture change according to anthropologist Homer Barnett. "Finally," he says (Barnett, 1941, p. 171), to put the finger on the ultimate source of all cultural change (emphasis mine, L.A.W.), it may be bold but it is not unreasonable to suggest some kind of personal conflict as the primary motivation for invention. In other words, there are good reasons for believing that the inventor is such because he feels, rather acutely and personally, a dissatisfaction with the customary and accepted ways 
of doing things. This is demonstrably true of the social inventor, the "liberal," and it is no less reasonable to posit some motor or affective thwartings at the source of technological inventions." Barnett excepts "the professional inventor of our nineteenth and twentieth century civilization" from this generalization. The professional inventor "does not really alter the picture," says Barnett; he merely "adds to it." And, finally, Boas (1938, p. 202) believed that culture changes were brought about, "in part at least," by "non-conformists."

\section{Comment}

Here is another simple and easy explanation of the process of culture change. If an individual doesn't like his culture he changes it. If he is a "dominant personality" or a "creative soul" he modifies or improves his culture as a sculptor shapes a piece of marble under his hands. Or, if the individual is maladjusted, if he suffers from "personal conflicts," or is simply a "non-conformist," he sets about to change the culture and make it more to his liking. Here again we find the simple, easy, anthropocentric explanation. As a matter of fact, it reminds us of the Deistic explanations in Genesis. To paraphrase this Book, we might speak as follows: "And Man surveyed the culture he had made and was not pleased with his handwork. He therefore said, 'Let there be change,' and there was change." Anthropomorphism is simply Deism reduced to human dimensions.

As for Boas' culture "running counter to his ideals," he obviously had no understanding of the origin and substance of his ideals. He believed that they originated within himself, not only independently of his culture but in opposition to it. He did not realize that he was born without ideals and that had he grown up outside a cultural tradition he would have had no more ideals than a gorilla; ${ }^{1}$ or, that if he had been reared in a Tibetan household he would have acquired different ideals. Boas' ideals were expressions of his culture just as his language, beliefs, and table manners were. The opposition between his ideals and his culture was due to the fact that a complex culture like our own is not homogeneous and wholly self-consistent. On the contrary, it is divided against itself at many points. Boas' personal conflict was also a conflict within his culture.

I shall not criticize in detail the Great Man theory of history here inasmuch as I have done so at some length elsewhere (e.g., in "Ikhnaton: the Great Man vs. the Culture Process," "Genius: Its Causes and Incidence," "Cultural Determinants of Mind," etc., in The Science of Culture.) The culturologist does not maintain that the individuality of human beings is wholly irrelevant to a

1 The individual "is nothing, at best an idiot; only through spoken intercourse in society does he become conscious of thought, is his nature realized. The thought of society, social thought, is the primary result and the thought of the individual is won by later analysis from it" Adolph Bastian, Die Vorgeschichte der Ethnologie, p. 79; 1890. These words were quoted by Ludwig Gumplowicz in The Outlines of Sociology, p. 45 (Philadelphia, 1899), who commented: "These words are golden and we shall accept them as the motto of sociology." 
scientific explanation of the process of culture change. Human organisms are the medium through which the culture process expresses itself; they are the instruments by means of which the culture process effects its changes and produces its results. And, since no two human organisms are alike in neurological, glandular, muscular, sensory, etcetera, structure and organization, the behavior of the culture process is conditioned by biological variations. No two people speak the English language exactly alike, and the particular and unique biological characteristics of the organism which is the head of a state affect the behavior of that sociocultural system. But, we might note four significant facts here in this connection.

In the first place, the Great Man, as a head of state, is a person who has been selected by a sociocultural system, i.e., the nation, and placed in that position. Hitler was placed at the head of the German nation by the nation itself, operating, of course, as all modern nations do through the groupings of powerful political, economic industrial, and military forces; it was not the little rabble rouser who captured the German nation single handed. A person becomes a Great Man in history when and because he is placed, by forces and agencies outside himself, in the midst of powerful cultural processes. Had not the Civil War come along and swept Ulysses S. Grant into its vortex, he would have remained an obscure and insignificant clerk in his father's leather store in Galena, Illinois.

Secondly, anyone who is selected by a sociocultural system and placed in a position of political power is, and must be, a person who is susceptible to social influence and the more the better; a person who was wholly impervious to social influence would not only not be an asset, but a serious liability.

Thirdly, to be a significant factor in the process of sociocultural change, a man does not need to be a "dominant personality" or a "creative soul." In fact, he may be a most mediocre person. If we grant - as we do - that the course of the Russian Revolution in 1917 was appreciably, or even profoundly, affected by the unique and innate traits of Nicolai Lenin, then we must also admit that a stupid and nondescript switchman could have had a like influence upon the course of events if he had forgotten to close a switch, thus wrecking the train which was bringing Lenin to Petrograd, and killing Lenin. Indeed, the course of history can be significantly affected by non-human beings. It was a goose who saved Rome, and Mrs. O'Leary's cow set the city of Chicago on fire.

Finally, the head of a great state has actually less individuality and freedom of action than an ordinary citizen in lesser walks of life. The President of the United States today enjoys less freedom of action and has fewer choices of alternatives than I. In his public and his personal life he is under constant surveillance and control by secret service men, newspaper reporters, and by the general public. He is not as free to do as he pleases, to go where he wishes, as I am. I could go to a Florida resort for a long week end with a spouse not my own with much greater anonymity and with fewer risks than could the President. With regard to decisions, I have greater freedom and control. The President's decisions can hardly be called his own at all. He is "briefed" by his aides, counselled by his advisors, pushed and pulled by countless political factions and 
economic interests. His "decisions," therefore, are but the expression of an integration and synthesis of literally thousands of social and political processes which belong to the body politic. The chief executive is but the meter which measures them and the mouthpiece which gives them expression. And I compose my own lectures; no one writes them for me.

To test our theory, let us imagine the President making a decision of his own. Suppose that he should, upon arising some morning, decide and declare that the United States should immediately and forthwith embark upon a program of absolute and complete unilateral disarmament. This would come about as close to being a decision of his own as would be possible. What would be the consequences? It is likely that the President would be quietly and unostentatiously removed to some secluded sanitarium where he could do no harm. In certain "non-democratic" countries he might well be shot or poisoned. The nation could not tolerate such an individual. The sudden termination of our vast munitions industries and the collapse of our economic system could not be permitted to take place.

But I am not a wholly free, discrete, autonomous individual, either. I must work within the limits of the structure and behavior of my University; and I must behave within the boundaries of the folkways and mores of my residential community. I do indeed compose my own lectures, but that simply means that I synthesize materials bestowed upon me by a scientific tradition. I can decide - but again within the limits of the Department of Anthropology - whether I will give a course on ethnological theory or primitive economics. But I cannot tell my students that man was created in the year 4004 B.C., or that the earth is flat and motionless. In my private life - and I have much more life that is private than does the President - I have much freedom to come and go as I please, and do what I wish. But always as a consequence of the values and goals that my culture has given me.

There is emphasis upon individuality and individualism at still another point in American anthropology. Franz Boas was "of Jewish extraction" (Lowie, 1947, p. 310). The exasperating phenomenon of anti-Semitism was of much concern to Boas not only in his formative years, as Kluckhohn and Prufer (1959, p. 10), have pointed out, but throughout his entire life. Many of his more prominent students were Jewish, also. ${ }^{1}$ As members of a minority group, many anthropologists of the Boas school were much concerned with the question of racial conflicts. The Mind of Primitive Man (1911; rev. ed., 1938), undoubtedly Boas' best known book, has race as its central thesis, and Race and Democratic Society, a volume of essays and lectures by Boas, published posthumously (1945), is much concerned with race problems.

In his discussion of race Boas exalts the individual and minimizes the significance of race. "Many hereditary characteristics," he says, "are not racial

1 John Sholtz, writing in Reflex: a Jewish Magazine, comments upon "the disproportionate position held by Jewish scientists" in the field of anthropology in the United States, p. 9. ("Durkheim's Theory of Culture," Reflex, 6:9-12, 1935). 
in character, but must be assigned to family lines... any generalized characterization of a race must be misleading" (Boas, 1945, p. 26). And "if it can be shown that each family line differs in its hereditary traits from all others then it would be impossible to speak... of hereditary traits common to the whole group [i.e., race]" (ibid., p. 31). As a matter of fact, Boas comes rather close to making race disappear. "When we talk about the characteristics of a race as a whole," he says, "we are dealing with an abstraction which has no existence in nature" (ibid., p. 70). If it could be shown that races do not really exist, then a logical basis for racial prejudice and discrimination would be removed. Unfortunately, prejudice does not need a logical basis in order to flourish.

Boas made a desperate effort to subordinate race to the individual. He does not go as far as to say that a race is "nothing but" a plural number of individuals. But he does quote "the eminent German anthropologist, Eugen Fischer, [who] went so far as to say - before the Hitler revolution - that every individual is a racial unit" (ibid., p. 44). And again and again he declares that members of minority groups "have the right to be treated as individuals, not as members of a class [race]" (ibid., p. 79). "According to our modern theoretical standards," he says, "we maintain that justice should be given to the individual, that it should not be meted out to him as to a representative of his class [race]" (ibid., p. 79).

Other members of the Boas school were ardent individualists, also. In his essay, "Why I am not a Marxist," Goldenweiser gives, as one of the reasons, at least, that he was an arch individualist (Goldenweiser, 1935, p. 75). And, as we have already seen, Sapir regarded the individual as a prime mover, the creator and determinant of the culture process.

This emphasis upon the individual in American anthropology had much to do, in my opinion, with the origin and development of the "Personality and Culture" movement that was so popular during the 1930s. As early as 1923, according to Ruth Benedict, a close associate and colleague of Boas, Professor Boas believed that his campaign to establish diffusionism in the place of evolutionism had been successful, and that "as he saw it, anthropology should spend its energies answering these questions of the interplay of the individual and culture" (Benedict, 1943, p. 61). In 1930 Boas stressed the need for "a penetrating study of the individual under the stress of the culture in which he lives" as opposed to studies of historical reconstruction (Boas, 1930, p. 269). In his Presidential address to the American Association for the Advancement of Science in 1932, he observed that "problems of the relation of the individual to his culture... have received too little attention. The standardized anthropological data that inform us of customary behavior, give no clue to the reaction to his culture, nor to an understanding of his influence upon it. Still, here lie the sources of a true interpretation of human behavior. It seems a vain effort to search for sociological [not cultural, or culturological, L.A.W.] laws disregarding what should be called social psychology, namely, the reaction of the individual to culture. They can be no more than empty formulas that can be imbued with life only by taking account of individual behavior in cultural settings" (Boas, 1932b, pp. 257-59; emphases mine, L.A.W.). And in one of the last articles he ever wrote, published 
posthumously, Boas could say that "one of the characteristic traits of modern anthropology" was "the emphasis laid on the relation between individual and culture..." (Boas, 1943, pp. 313-14).

Thus we find in the social philosophy and social science of American scholars a coherent philosophy of reality: of society, culture, and the individual. In this philosophy, the individual is not only first and foremost, but in extreme cases, the only reality. "Every society," says Ralph Linton, "is, in the last analysis, a group of individuals" (Linton, 1945, p. xiv). But a society is merely a "conceptual construct" (Kluckhohn and Kelly, 1945, p. 80), and culture but an imperceptible abstraction (see White, 1959a, pp. 227-28). If culture is imperceptible does it really exist? One anthropologist has summarized contemporary thinking on this point by declaring that "culture has no ontological reality" (Spiro, 1951, p. 24). In its extreme form, this philosophy holds that only the individual is real. This is more frequently implicit than explicit. But sometimes it is asserted in a forthright manner. We recall a distinguished German sociologist, Georg Simmel (1858-1918), who, after surveying phenomena ordinarily called social and cultural, declared that "it is certain that in the last analysis only individuals exist" (Simmel, 1898, p. 665; see, also, Vierkandt, 1934, p. 61).

We hold that this philosophic view of man and culture is but a simple, and rather crude form of anthropocentrism. Its concepts rest directly upon and immediately express, percepts. One can see an individual, therefore he exists. One cannot see culture therefore it "has no ontological reality." This view is made explicit by one of the anthropologists in Kluckhohn and Kelly's imaginary symposium (1945, p. 81). He expresses his dissatisfaction with the concept of culture, saying: "I maintain that we would get further if we stuck to human interaction with other humans and with the natural environment. You can see those things, but has any of you ever seen 'culture'?"

This self-imposed limitation upon the intellect is pathetic. One might argue that no one ever saw a vegetable, but only carrots, onions, etc.; or that no one can see a university, but only this building and that. "Vegetable" is the name of a class of phenomena, and members of this class can certainly be seen. "University" is the name of interrelated, real, observable things and events. To limit the exercise of the intellect to optical perception is to make science utterly impossible. No one ever saw the solar system with his eyes, but only the sun and planets. But the scientist "sees" with the eyes of his mind, not merely with his retina, optic nerve, and so on. The naiveté of the anthropomorphic conception of culture is made apparent by imagining the observer equipped with a different kind of eyes. Suppose he had eyes that could clearly distinguish the cells of the human body. Then he would declare that "in the last analysis" - he would, of course, have to say, "in the last analysis" - only cells are real; a human being is merely an anatomical construct. If he had eyes that could distinguish molecules or atoms, then they would, in the last analysis, be the only realities. And if he had the ultimate in microscopic vision, he would find that only electrons, protons, mesons, etc., are real, that even atoms are but logical constructs. And, at the other end of the spectrum, if our observer had macroscopic vision perhaps 
he could not see individuals at all, but only crowds; only forests, no trees. Are we to tolerate a philosophy in which the nature of reality is determined by variations of optical perception?

To be sure, science must postulate a real world external to and independent of the observer ${ }^{1}$. And our knowledge and understanding of this external world must arise out of and depend upon our sensory perceptions of it (see Einstein, 1936, pp. 350 et passim). But to think of perceptions as the starting point of knowledge and understanding is one thing; to limit conceptions to the narrow boundaries of perceptions is quite another matter. And it is conceptions that count in science.

One might argue that one cannot see a football team, but only the individual players. But then he would be obliged to say, if he were consistent, that he could not see a quarterback at all, because a quarterback is an individual in a network of relationships and one cannot see "a network of social relationships". Similarly, one could not see a slave because he could perceive only the biological object, not the institution of slavery. Corn and cotton are not commodities per se; they become commodities only when they are significant in certain contexts. These contexts are not observable via the retina and optic nerve; they are conceptions. And conceptions are the building blocks of science. One cannot well imagine a more effective way to sabotage scientific endeavor than to limit it to sensory perceptions.

To return now to the three major concepts of the science of man and his work: the individual, society, and culture.

The individual is first of all, a physical object. It is discrete, it has weight and dimensions. And, although it resembles other members of its class, it can be distinguished from them by its possession of more or less particular characteristics. Secondly, an individual is a biological organism. A biological organism is, of course, still a physical object, but it is one whose individuality has been determined in part by other biological organisms, namely, its ancestors. As a biological organism, an individual is an expression of a network of relationships as well as being a discrete and autonomous system. Thirdly, a member of the species Homo sapiens would, as a mere animal, be a member of a society if there were in actuality any such thing as human men apart from culture. Man cannot, therefore, be merely a social animal, but only a socio-cultural animal which is not a mere animal but a human being (see White, 1959b). Finally, a human individual is a member of a socio-cultural system. As such, his individuality is determined by the extrasomatic cultural tradition in which he lives as well as by his own biological equipment. And, as we have seen, the cultural tradition completely overrides the biological basis of behavior, at least as far as groups, peoples, are concerned. And even in the case of individual organisms one's religion, values, customs and beliefs are determined by one's culture rather than by one's nerves, glands, muscles and sense organs.

To return to Simmel's dictum that only individuals are real, we must ask

1 "The belief in an external world independent of the perceiving subject is the basis of all natural science" (Einstein, The World As I See It, p. 60, New York, 1934). 
what is the nature of the reality - or of the several realities - that the human individual has. We have just reviewed the three levels of reality: physical, biological, and socio-cultural. Every individual is, by definition, a member of a class. As a physical object, a human individual is both discrete and independent. As a biological organism it is discrete in one sense but a point in a network of genetic relationships in another. And as a human being the individual is primarily and predominantly an expression of a particular synthesis of cultural elements; his individuality is even less as a human being than as a biological organism. As Karl Marx observed many years ago: "But the essence of man is no abstraction inherent in each separate individual. In its reality it is in the ensemble of social relations" (VIth of the Theses on Feurbach).

What then are we to say about society and culture whose reality has often been questioned or denied, in contrast with the attribution of reality to individuals? As soon as we disabuse ourselves of the notion that only those things that we can see are real, and after we have distinguished between seeing with retinas and optic nerves, on the one hand, and, on the other, seeing with the mind's eye, the eye of science, we shall have no trouble.

Society is the name that we give to a plural number of individuals who interact with one another. A society is a network of relationships among individuals. The relationships and the network are as real as the individuals. It is nonsense to say that the Earth is real and the Sun is real - because we can see them - but that the relationship between them is not real because we cannot see it. "Relationship" is a concept in the mind of the scientist, but the concept corresponds to an observable reality in the external world. It is the same with "fox," "gene," or "electron." These are both concepts and things or events in the external world.

And so it is with "culture." "Culture" is the name that anthropological science has given to a class of phenomena. These phenomena are as real as stars or atoms, and, like stars and atoms, they exist in the external world, locatable in terrestrial time and space. Culture is the name of things and events dependent upon man's unique ability to symbol, considered in an extrasomatic context (White, 1959a, p. 234). "Things and events dependent upon symboling" include language, beliefs, customs, tools, utensils, works and forms of art, and so on. A thing or event is said to be in a somatic context when it is considered in terms of its relationship to the human organism. It is in an extrasomatic context when it is considered, not in terms of its relationship to the human organism, but in terms of itself and in terms of its relationship to other things and events. Thus, when we consider the mother-in-law taboo in a somatic context we are concerned with the conceptions, attitudes and acts of the persons concerned. When we consider it in an extrasomatic context we are concerned with the relationship of this taboo to other customs such as place of residence after marriage, the division of labor between the sexes, customs of inheritance, and so on. Things dependent upon symboling considered in a somatic context we call human behavior; when considered in an extrasomatic context we call them culture (see White, 1959a, p. 231). 
To say that society and culture are not real because one cannot "see" them is nonsense, scientific nonsense. One might as well say that the solar system or the Supreme Court is not real. Or, as we have said before, one might as reasonably argue that the individual is not real, that only cells, molecules, atoms, or subatomic particles are real. Anthropomorphism, anthropocentrism - the exaltation of the individual human being - as a philosophic tradition is old and well established in the cultures of the world. It is not only pre-scientific; it is antiscientific. It is one of the greatest, if not the greatest, obstacle to the achievement of the sciences of man, culture and society that we can think of. But, in competition with the non-anthropomorphic conceptions of science it will eventually be rendered obsolete and liquidated.

Literature Gited

ANDERSON, NeLS

1923 The Hobo: The Sociology of the Homeless Man, Chicago.

BARNETT, HOMER G.

1941 "Personal Conflicts and Cultural Change," In: Social Forces, Vol. 20, pp. 160-171.

BENEDICT, RUTH

1934 Patterns of Culture, Boston.

1943 "Obituary of Franz Boas," Science, Vol. 97, pp. 60-62.

Boas, Franz

1930 "Some Problems in the Methodology of the Social Sciences," In: The New Social Science, Leonard D. White, ed., Chicago.

1932a Anthropology and Modern Life, revised edition, New York.

1932b "The Aims of Anthropological Research," Science, Vol. 76, pp. 605-613. (Reprinted in F. BoAs, Race Language and Culture, 1940).

1938 "An Anthropologist's Credo," In: The Nation, Vol. 147, pp. 201-204.

1943 "Recent Anthropology," In: Science, Vol. 98, pp. 311-314.

1945 Race and Democratic Society, New York.

Gassirer, ERnst

1944 An Essay on Man, New Haven, Connecticut.

EINSTEIN, Albert

1936 "Physics and Reality," In: Journal of the Franklin Institute, Vol. 221, pp. 313-347

Firth, Raymond in German, pp. 349-382 in English.

1951 Elements of Social Organization, London.

Goldenweiser, AleXander

1922 Early Civilization, New York.

1935 "Why I am not a Marxist," In: The Modern Monthly, Vol. 9, pp. 71-76.

Hediger, Heini $P$.

1961 "The Evolution of Territorial Behavior," In: The Social Life of Early Man, Sherwood L. Washburn, ed., Chicago.

JAMES, WILLIAM

1880 "Great Men, Great Thoughts and their Environment," In: Atlantic Monthly, Vol. 46, pp. 441-459.

Kuuckhohn, Glyde and William H. Kelly

1945 "The Concept of Culture," In: The Science of Man in the World Crisis, Ralph Linton, ed., pp. 78-106, New York.

Klugkhohn, Cryde and Olaf Prufer

1959 "Influence during the Formative Years," In: The Anthropology of Franz Boas, Walter Goldschmidt, ed. Memoir 89, American Anthropological Association, pp. 4-28. 
KoHLeR, WolFGang

1926 The Mentality of Apes, New York.

Kroeber, A. L. and Glyde KLUCKHohN

1952 Culture, A Critical Review of Concepts and Definitions. Papers of the Peabody Museum of American Archaeology and Ethnology, Vol. 47 (1). Cambridge, Massachusetts.

Linton, RALPH

1938 "The Present Status of Anthropology," In: Science, Vol. 87, pp. 241-248.

1945 The Cultural Background of Personality, New York.

LOWIE, ROBERT H.

1947 Franz Boas, 1858-1942. Biographical Memoirs, National Academy of Sciences, Vol. 24, pp. 303-322.

1948 Social Organization, New York.

LYND, ROBERT S.

1939 Knowledge for What? Princeton University Press.

MALINOWSKI, BronisLAW

1939 "The Group and the Individual in Functional Analysis," In: American Fournal of Sociology, Vol. 44, pp. 938-964.

SAPIR, EDWARD

1916 Time Perspective in Aboriginal Culture, A Study of Method, Memoir 90, Canada Department of Mines, Ottawa.

1917 “Do We Need a Superorganic?" In: American Anthropologist, Vol. 19, pp. 441-447.

Simmel, Georg SPIRO.

1898 "The Persistence of Social Groups,"In: American Journal of Sociology, Vol. 3, pp. 662-98.

1951 "Culture and Personality," In: Psychiatry, Vol. 14, pp. 19-46.

VIERKANDT, A.

1934 "Georg Simmel, 1858-1918," In: Encyclopedia of the Social Sciences, Vol. 14, p. 61.

White, Leslie $A$.

1942 "On the Use of Tools by Primates," In: Fournal of Comparative Psychology, Vol. 34, pp. 369-374. Reprinted in Man in Contemporary Society, Columbia University, Vol. I, pp. 58-64, 1955; in Readings in Introductory Anthropology, Elman R. Service, ed., Ann Arbor, Michigan, 1956; and in Reprints Series in the Social Sciences, BobbsMerrill Co., 1962.

1949a The Science of Culture, New York: Farrar, Straus \& Co.; reissued in paperback by The Grove Press, 1958.

1949b "The Individual and the Culture Process," In: Journal American College of Dentists, Vol. 16 (1), pp. 3-10.

1950 "The Individual and the Culture Process," In: Centennial, American Association for the Advancement of Science, Washington, D.C. (This is an entirely differently worded equivalent of $1949 \mathrm{~b}$ ).

1959a "The Concept of Culture," In: American Anthropologist, Vol. 61, pp. 227-51. Reprinted in Portuguese translation in Educaçao e Ciências Sociais, Vol. 8, No. 14, pp. 17-56, 1960 (in Rio de Janeiro, Brasil); in Culture and the Evolution of Man, M. F. Ashley Montagu, ed., pp. 38-64, New York, 1962; and in Reprint Series in the Social Sciences, The Bobbs-Merrill Co., 1962.

1959b "Man, Culture and Human Beings," In: Michigan Alumnus Quarterly Review, Vol. 66, pp. 1-6.

1962 "Symboling: A Kind of Behavior," In: The Journal of Psychology, Vol. 53:311-317.

Williams, ROGER J.

1950 "The Human Frontier," In: Centennial (papers presented at the Centennial of the American Association for the Advancement of Science in Washington, D.C., 1948). Washington, D.C.

WisSLER, GLARK

1927 "Recent Developments in Anthropology," In: Recent Developments in the Social Sciences, E. C. Hayes, ed. Lippincott. 